\title{
Priority directions and methods of the counteraction to the informal economy in the regions of Russia
}

\author{
Yulia G. Kopylova \\ Volgograd State University, \\ Institute of Economics and Finance, \\ Chair of the Economic Theory, \\ World and Regional Economics \\ Volgograd, Russia \\ kopilovajg@volsu.ru
}

\author{
Elena G. Russkova \\ Volgograd State University, \\ Institute of Economics and Finance, \\ Chair of the Economic Theory, \\ World and Regional Economics \\ Volgograd, Russia \\ russkovaeg@volsu.ru
}

\begin{abstract}
The low efficiency of the system of the counteraction to the informal economy in the regions of Russia determined the necessity of the search of the practical measures in the reduction of the informal sector of the economy in the practice of foreign states. The authors suggested the main directions of the economic policy at the macro and the meso levels within which the methods (economic and administrative ones) and the measures (reduction of the combined tax rate, increase of the number of administrative inspections in the enterprises, number of the labour inspectors, standardization and simplification of the business registration and so on) counteracting to the informal economy. The marginal analysis of the foreign experience of the practical realization of the mentioned measures resulted in the construction of the graphical model which allows determining the most efficient of them. The authors showed the importance of the suggested measures for the development of the counteraction system to the informal economy in the regions of Russia.
\end{abstract}

Keywords - non observable economy, informal economy, economic policy, directions of the economic development

\section{INTRODUCTION}

The competitive ability, sustainability and the security of the development of the economic systems is determined in many aspects by the informal constituent in the national economy and the economies of the regions. The presence of the informal or non observable economy has a negative impact on the profitable part of the budgets of all levels, on the indices of the gross domestic product, of the gross regional product and of the social development of the society. That's why the government authorities set the goal of the reduction of the informal sector in the result of the creation and of the implementation of the policy of the counteraction to the informal economy.

The efficiency of the interaction to the informal (shadow) economy in most part of the developed countries is considerably higher than in the Russian Federation. In the opinion of many experts the share of the informal part in the GDP of Russia varies from $22,5 \%$ [1] to $39,07 \%$ [2]. The data of the research of the Association of the Chartered and Certified Accountants (ACCA) show that the share of the informal sector in Russia is $84 \%$ higher than in average throughout the world in average» [2]. At the same time the forecasted dynamics of the world indices in contrast to the Russian ones will reduce by the year 2025 [2].

A similar dynamics is observed also in the regions of the country. In the ratings of the subjects of the federation of Russia (further the regions of the Russian Federation) upon the share of the employed in the informal sector of the economy a constant leadership belongs to the republics with an undeveloped industry or a high unemployment rate. The first ranks of the rating the following regions occupy the leading positions: Chechen republic has $63,3 \%$ of the total number of the population working in the informal sector; republic of Daghestan has 55,7\%; Kabardino-Balkar republic has 50,4\%; Ingushetia republic has $50,1 \%$; republic of Kalmykia has $37,5 \%[3]$.

The problems of the theory of the counteraction to the informal economy are studied in the papers of both foreign ( $\mathrm{F}$. Shneider, E. Weiseberg) and Russian scientists (V.Yu. Burov, $\mathrm{Yu}$. Latov and others. However for the present moment there is no comprehensive research which would become the theoretical basis of the counteraction to the informal economy in the Russian regions.

In this respect a special importance has the goal of the present paper. The suggestion of the priority directions of the development of the existing system of the counteraction to the informal economy in the regions of Russia, the suggestion of the development of the efficient measures and the measures of the economic policy of the state authorities having a considerable impact on the decision making of the economic actors concerning the functioning in the official sector of the economy became the goal of this research.

The achievement of the goal set requires the solution of the following tasks. 
First of all it is necessary to construct the basic hypothesis of the research on the basis of the supposition that irrespectively to the geographic location and to the social and economic development of the economic system the suggestion of the internal measures of the counteraction to the informal economy is possible. Among which it is indispensable to find the efficient measures for their further use in the Russian circumstances.

Secondly, it is necessary to make a comparative analysis of the directions of the development of the system of the counteraction to the informal economy in the regions of Russia and in a number of the European countries.

Thirdly, within the comparative approach it is important to carry out the marginal analysis of the measures used at the realization of the state policy in the sphere of the informal economy of the studied economic systems.

Fourthly, it is necessary to construct the graphical model on the basis of the results of the marginal analysis which allows classifying the measures according to the character of their influence on the share of the informal economy (economic, administrative and legal measures) and according to the degree of their efficiency for the analysis of the potentially usable tools of the counteraction to the informal economy in the regions of Russia.

\section{MATERiAls AND MethodS}

For the study of the positive foreign experience of the reduction of the share of the informal economy it is relevant to make the comparative analysis of the measures used by foreign states in the fight with the informal economy. The main criterion of their choice is determined by the positive changes of in the share of the informal economy in the result of their use. The geographical characteristic in this case is second best as it does not have a definite impact on the share of the informal economy in comparison with the measures for its reduction used within the realization of the economic policy. In order to assess the efficiency of every measure it is indispensable within the mentioned analysis to carry out the marginal analysis of the impact of the economic and administrative measures of the governmental policy on the share of the informal economy.

Taking into account the relationship between the share of the informal economy and the social and economic factors it is needed to describe it as a functional relation $y=f(x)$, where:

$y$ is a dependent variable presenting the share of the informal economy and the values characterizing it, such as tax revenues into the government budget, number of the officially employed in the economy, number of the registered firms and so on.

$x$ is an independent variable which presents a qualitative expression of the factor influencing the share of the informal economy. The change of this index from the part of the government is also a tool for its economic policy in respect of the informal economy.

In order to carry out the marginal analysis of the influence of the economic and administrative measures on the informal economy the calculation of the marginal value of the dependent variable is needed. This index presents the change of the dependent variable in respect to the change of the factor influencing it (tool of the economic policy used in the correlation with its measures).

$$
M y=\Delta y / \Delta x(1), \text { where: }
$$

My is the marginal value of the dependent variable showing the change of the dependent variable $(\Delta y)$ when the independent variable $(\Delta x)$ increases by $1 \%$. My characterizes the marginal efficiency of the measures of the economic policy of the government in the informal economy or it shows the efficiency of every unit of a changed factor used as a tool in the governmental policy in the reduction of the share of the informal economy.

According to the rules of the marginal analysis the efficient measure in the informal economy is the one at which the marginal value of the dependent variable is $>0$.

However it is worth mentioning that the closer the value of the dependent variable to 0 is, the less efficient the measures of the governmental policy in the informal sector are as in this case they do not result in the change of the dependent variable. And vice versa the further the mentioned value is from 0 , the more efficient the measures taken are.

Thus in compliance with the index of the marginal value of the dependent variable it is indispensable to rank the measures of the economic policy of the government in the informal economy according to the degree of their efficiency in the following way: $[0 ; 0,5]$ - low efficiency; $[0,5 ; 1]$ — average (single) efficiency; $(1 ;+\infty)$ - high efficiency.

The statistical base of the current research are the estimates obtained on the basis of the empirical data of the Russian and foreign researchers, international, foreign and Russian organizations (governmental and non governmental), scientific and research centers, institutes and libraries.

\section{RESULTS AND DISCUSSION}

Within the comparative and marginal analysis it is worth studying the positive experience of the reduction of the share of the informal economy in foreign economic systems taking into account the classification of the basic direcions and the methods in the main spheres and the methods of the system of the counteraction to the informal economy presented in Table 1. It is worth noticing that the methods mentioned above in specific countries and the regions acquire the specific characteristics in compliance with the peculiarities of the informal economy, social, economic, political and other factors. It is necessary to analyse these measures in detail. 
TABLE I. SPHERES OF THE POLICY OF THE COUNTERACTION TO INFORMAL ECONOMY

\begin{tabular}{|c|c|c|c|c|c|}
\hline Methods & Taxation & Social Provision & Regulation of entrepreneurial activity & $\begin{array}{l}\text { Regulation of } \\
\text { labour activity }\end{array}$ & $\begin{array}{l}\text { Regulation of monetary } \\
\text { supply }\end{array}$ \\
\hline $\begin{array}{l}\text { Economic } \\
\text { method }\end{array}$ & $\begin{array}{l}\text { Reduction of the tax } \\
\text { burden }\end{array}$ & Increase of the living standard & $\begin{array}{l}\text { Reduction of the transaction costs of } \\
\text { enterprises }\end{array}$ & $\begin{array}{l}\text { Encouragement of } \\
\text { the actors of the } \\
\text { labour market }\end{array}$ & $\begin{array}{l}\text { Economic encouragement } \\
\text { of the cashless transfer }\end{array}$ \\
\hline $\begin{array}{l}\text { Administrative } \\
\text { method }\end{array}$ & $\begin{array}{l}\text { Standardization and } \\
\text { simplification of the } \\
\text { tax xystem }\end{array}$ & $\begin{array}{l}\text { Support of the small business, } \\
\text { improvement of the social } \\
\text { legislation }\end{array}$ & $\begin{array}{l}\text { Removal of administrative barriers, } \\
\text { business registration, minimization of } \\
\text { bureaucracy, reduction of corruption level }\end{array}$ & $\begin{array}{l}\text { Flexibility of } \\
\text { labour legislation }\end{array}$ & $\begin{array}{l}\text { Business transactions } \\
\text { both in cash and cashless } \\
\text { forms }\end{array}$ \\
\hline
\end{tabular}

Source: made by the authors

\section{A. Taxation}

One of the most efficient measures in many European countries is the encouragement of the economic actors to work in the official sector of the economy. In the last ten years many countries of the Eastern Europe including Bulgaria, Czech Republic, Hungary offer various tax remissions, set tax rates low enough for individuals and legal entities (i.e. economic methods). According to the data of the World bank the reduction of the tax load in Bulgaria in 2008 from 35,8\% to $33,9 \%$ (by $1,9 \%$ ) has lead for the moment to an increase of tax revenues by $5,24 \%$ per year [4] what speaks about the growth of the economic indices of the official sector of the economy. The marginal revenue of the dependent variable calculated earlier (these are the official tax revenues into the budget of the government) equal to 2,76 speaks about a high efficiency of such measure as it characterizes practically threefold return from the reduction of the tax burden for a percent.

In the Russian Federation over recent years the growth of the tax burden on business is observed. Since January, $1^{\text {st }} 2013$ the pension contributions for individual entrepreneurs considerably grew. If in 2012 the pension tax made up 14386 rubles per year then in 2017 this contribution amounted to 23 400 rubles per year. As for the regions of the Russian Federation all the leading regions upon the share of the informal economy also have the maximal (more than 20\%) or middle rate $(10-20 \%)$ of the tax burden. This fact proves the necessity of the reduction of local taxes and duties into the budgets of the mentioned regions [5].

The reduction of the tax burden in many foreign countries is a priority measure or even a complex of measures joined by the objects into the following groups: specific tax types, tax payers, mixed measures implying the reduction of the tax rates and also the weakening of the tax pressure on the socially unprotected population.

The example of the first type is the reduction of the corporate tax which is used in Hungary, Poland, Slovakia and Estonia (tax remissions for the entrepreneurs on the reinvested revenues). For the reduction of the informal economy in the Netherlands and in Great Britain the tax remissions are given to the firms for the creation of new working places.

The second group of measures is presented by the reduction of the total tax burden on the socially unprotected (Hungary) population or newly employed people
(Montenegro). These measures reduce the risk of the transfer of people with unstable incomes into the informal economic sector.

The mixed measures dealing with this the reduction of the tax burden are used for example in Turkey where the tax amnesty in 2005-2010 took place and it allowed transferring a big number of firms from the unregistered status into the official one. Also in some countries (Bulgaria, Belgium, Netherlands, France) the authorities used not the reduction of the tax rate but the increase of the "threshold" of the taxable income as a tool of the counteraction to the informal economy by means of the reduction of the tax burden. However in Bulgaria the efficiency of such a measure proved to be sufficiently low (the marginal rate made up 0,07).

When analyzing the administrative methods it is worth mentioning that some countries (Austria, Greece, Netherlands, France, Portugal, Denmark) in their tax policy for the reduction of the share of the informal economy use the simplification and the standardization of the tax system. The simplification of the registration of enterprises and the introduction of the electronic system of tax payments are also used by the authorities of the countries mentioned above. This measure which is used for instance in Estonia is efficient enough as it allows reducing the administrative barriers for entrance into the official sector of the production and the distribution of goods and services.

It can be considered as a successful practice the reduction of the informal sector of the economy the experience of the countries of the Southern America (Argentina, Bolivia, Brazil, Chile, Costa Rica, Dominican republic, Guatemala, Honduras, Mexico, Nicaragua, Paraguay, Peru) where the value added tax and the income tax were replaced by a common (unified) tax. After the introduction of this measure many firms took the decision about the leaving the informal sector and about the official registration of the firms. For instance the adoption of this measure within the economic policy in respect to the informal economy allowed increasing the tax revenues in Argentina during the period $1990-2005$ from 16,1 to $26,9 \%$ of the GDP what speaks about the increase of the official sector of the economy and the reduction of the informal sector of the economy in the country [5].

The examples of the simplification of the tax system for small and medium sized business became Kenya, Tanzania, Uruguay, Brazil and Argentina. At the same time the integral system of taxes and contributions SIMPLES NATIONAL 
introduced in Brazil in 2012 which was expected to reduce the period of time for tax payments from the business proved to be insufficiently practical (the marginal index made up 0,37).

\section{B. Social security}

A low level of the social security in a nation is one of the basic reasons for the appearance and for the development of the informal economy in various countries and regions. Therefore the social support of the population contributes to the reduction of the reasons of the transfer of the individuals and legal entities into the informal sector of the economy. Among the social measures which are placed among the economic methods a special place is occupied by the encouragement for the firm's registration or for the employment of new workers. In many countries of the European Union the payments of social benefits proportionally to personal contributions and income taxes of the individuals are widely spread. And this in our opinion is an efficient measure of the reduction of the share of the unpaid taxes. For instance in Bulgaria the tax rates for the contributions of the social welfare were reduced. Latvia, Poland and Slovenia practice the transfer of the contributions from the employer to the employees. However the marginal analysis showed that in the situation of Latvia such a measure proved to be inefficient (the marginal index made up 0,1).

The administrative methods of the social policy play an important role in the reduction of the share of the informal economy as well. The undeveloped social infrastructure of the country can speak about a high share of the informal economy. The example for that is the experience of Sweden in the construction of the system of the social economy. The modern Swedish model has as the goal the social leveling. Thanks to that at other equal conditions among the economic actors of Sweden (both individuals and legal entities) the reasons for the work in the informal sector of the economy are not significant. During a decade (from 2003 to 2013) the share of the informal economy of Sweden dropped almost twice (from 14,4 to 7,3\% of the GDP; according to the data of the World bank - from 18,6 to $13,9 \%$,) [6].

\section{Labour activity regulation}

According to the data of the Laboratory of the Market Research of the Labour Market of the Higher School of Economics the share of the employed in the informal economy of Russia reaches in average $25-30 \%$ across regions. According to the data of the Federal Service for State Statistics of the Russian Federation before the September 2009 about 270 thousand people were registered in the informal sector of the economy in Russia but in recent times this index reached about 800 thousand people. The general employment rate in Russia considerably supplies the informal sector of the economy thank to which the Russian labour market from 1999 grew by $7 \%$ and the informal economy increased 1,5 times or by $50 \%$. In the regional aspect mainly the regions of the Southern and the North Caucasian Federal Districts are in a worse condition. In the rating of the regions the republic of Ingushetia occupies the $66^{\text {th }}$ rank from 85 , the Chechen republic has the $76^{\text {th }}$ rank, the republic of Kalmykia has $77^{\text {th }}$ rank, the Kabardino-Balkar republic has $79^{\text {th }}$ rank [7].
Within the economic methods in the world practice one of the most wide spread of the government support used for the reduction of share of the informal economy is a flexible system of salaries. Within its frames the marginal increase of the minimal salary for the value of the index of consumer prices is used. Also this type of policy implies the introduction of a differentiated schedule of salaries according to some criteria (for instance by age, region and so on). Such measures used for instance in Poland assure in the country a necessary standard of living of the population allowing to reduce the encouragement of a partial or a complete transfer of the economic actors into the informal economy. In Lithuania and the countries of the Latin America (Chile, Columbia, Argentina, Brazil, Panama and Peru) the reduction of the discharge allowance was used. However in Columbia such a measure proved to be inefficient (the marginal index made up 0,27).

The measures of the government policy of the largest part of the foreign countries and in Russia in the sphere of the control of the implementation of the law in the labour legislation by the economic actors have mainly the administrative character. The countries of the European Union for the reduction of the informal economy increase the level of the material and technical supply for the monitoring of the unregistered workers, for the strengthening and for the creation of new monitoring agencies and also for the development of the relations between the establishments of various departments for the informational communication and for a possible elimination of the informal economy.

\section{Regulation of the entrepreneurial acitivity}

The main reason for the work of the business in the informal sector of the economy are the unfavorable economic conditions for the entrepreneurship with high transaction costs. That's why the main economic measures of the counteraction to the informal economy are the reduction of the transaction costs of the small and medium sized enterprises before all of the costs for the registration of the business and of the private property, interest rates on corporate credits and so on.

In connection with the Rating of the countries according to the conditions for business completed by the company «Ernst \&Young» for the countries of the Group Twenty the Russian Federation occupies the first rank upon the government support of business [8]. However in the rating of the business activity Russia has only the $123^{\text {th }}$ rank between Uganda and Uruguay [9]. It is worth mentioning that Russia lost several ranks in comparison with the previous year. The facts mentioned above testify the inefficiency of the largest part of the measures of the support of the small business in Russia. This in its turn does not result in the reduction of the share of the informal economy in the country and its regions.

It is time now to introduce a number of measures of the economic and administrative character in the creation of the favourable conditions for the business activity which allow reducing the transaction costs of the official sector of the economy and reducing the transfer of the entrepreneurs to the informal sphere of the economy. Such a practice is widely spread for instance in the countries of the European Union 
which provide together with the simplified conditions for the registration of the business activity the government support for business.

The administrative measures consist in the reduction of the share of the informal economy at the registration of business (starting from the legislation improvement in the property rights registration and finishing by the simplification of the procedure). As the example of the positive international experience in this sphere the changes in the registration procedure of enterprises which was realized in Mexico in 2002 can be used. The mentioned above program of the "quick registration of business" allowed reducing the period of the registration of small and medium sized firms up to two days and the number of the procedures was reduced from 8 to 2 . The result of the $75 \%$ reduction of administrative barriers lead to the transfer of the firms from the informal sector into the official sector of the economy and to the growth of the number of the officially registered companies from 4 to $8 \%$. The marginal index of the reaction of private enterprises to this measure of the economic policy in respect to the informal economy made up at the same moment 0,67 whereby the conclusion about its high efficiency can be made.

Similar measures are successfully used in Australia, Belgium, Estonia, Lithuania and other countries where the rule of "one window" for business registration is in force. The simplification of the rules of the licensing of the entrepreneurial activity is used also in the Russian Federation, Georgia, Uganda, Tanzania.

The example of an efficient use of the administrative methods of the reduction of the share of the informal economy is also the practice adopted in Brazil which increased the revenues from taxes on wages into the state budget and which achieved the reduction of the informal employment by $1,5 \%$ thank to more frequent (increase by 1\%) government controls of the firms. Another example is Argentina where the increase of the number of labour inspectors per capita and per 100000 of population lead to the growth of the official labour force in the private sector by $1,4 \%$. Having made the analysis of the changes we got the marginal values of the constant factor correspondingly: for Brazil it is 1,5, for Argentina it is 1,4. The indices mentioned above confirm a high efficiency of the measures taken of the counteraction to the informal economy.

\section{E. Regulation of the monetary supply}

The regulation of the monetary supply as a direction of the economic policy in case of the informal economy includes the economic methods. Thus the use of the electronic payment systems contributes to the growth of the transparence of the economic transactions and makes the work of the economic actors in the informal economy difficult. There exists a strong negative correlation between the electronic payments in the country and the share of its informal economy. For the countries with the developed system of electronic payments such as Great Britain and the countries of the Northern Europe smaller shares of the informal economy are typical than in the countries where this system is poorly developed (for instance in Bulgaria, Romania and Greece).
In the paper of F. Schneider «Informal economy in Europe, 2013» [10] it was proved that the increase of electronic transactions by $10 \%$ per year in average during at least of four years in sequence contributes to the reduction of the share of the informal economy by $5 \%$ in average. When analyzing the practice of the countries using the system of electronic payments and cashless transfers it becomes obvious that such a measure is characterized by an average level of the efficiency both in developed and in developing countries with a high level of technological development. About this speaks the marginal level of the changes of the average index assessing the share of the informal economy calculated for various countries and it equals 0,5 .

Thus the study of foreign systems of the counteraction to the informal economy allows in compliance with the spheres (taxation, social security, regulation of the entrepreneurial, labour activities and money supply) and methods of the economic policy (economic and administrative ones) suggesting the efficient measures in case of the informal economy.

The marginal analysis of the impact of the measures of the counteraction to the informal economy in various economic systems showed excellent results of the marginal value of the constant factor. In one system of coordinates it is worth ranking the measures mentioned above according to their efficiency (Figure 1).

The diagram shows that the most efficient measure of the government policy in case of the informal economy has an economic character and is expressed by the shape of the reduction of the total tax burden.

The measures which are directly connected with the fiscal systems of the states (for instance the reduction of the individual tax rate or measure № 2) are less efficient. Every administrative measure proved to be less efficient in comparison with the reduction of the total tax burden however their dispersion changes in the number of the marginal values of the dependent variable judging from the schedule are less significant. The administrative measures are characterized as the ones giving a less stable result in comparison with the economic measures. Nevertheless the average value of the efficiency of the economic measures is by 0,2 ranks higher than the analogous index for the administrative measures $(0,6$ and 0,4 correspondingly).

Judging from the mentioned above the conclusion can be made about a high significance of the economic policy of the countries and the regions in case of the informal economy. The measures both of the economic influence (reduction of the total tax rate, development of the system of cashless transfers and so on) and of the administrative and legal character (increase of the frequency of administrative controls at the enterprises, number of the labour inspectors, standardization, simplification of the business registration and so on) are useful. 


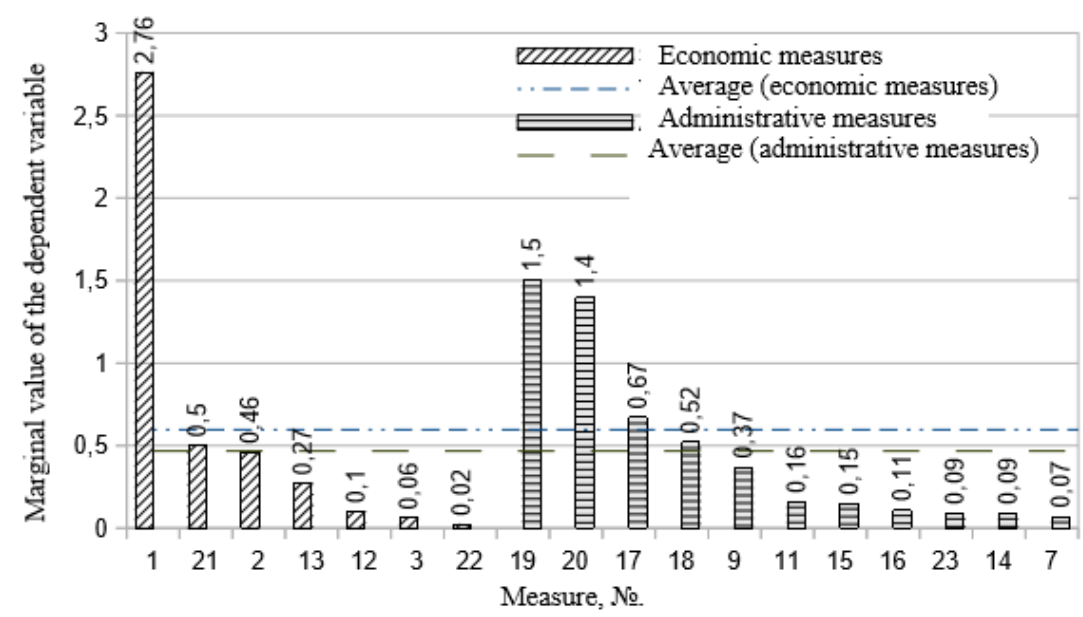

Here: 1) reduction of the total tax rate; 2) reduction of the income tax; 3) tax remissions; 7) growth of the threshold of the non taxable income; 9) simplification of the tax system; 11) growth of tax inspections; 12) transfer of social contributions from employers; 13) reduction of dismissal compensations; 14, 15) increase of the employers holding contracts; 16) simplification of the system of job search; 17) reduction of the registration time of an enterprise; 18) reduction of the procedures of the business registration; 19) increase of the frequency of administrative inspections; 20) increase of the number of labour inspectors; 21, 22) development of the system of the electronic payments; 23) reduction of the upper ceiling of cash payments.

Fig.1. Results of the marginal analysis of the measures of the counteraction to the informal economy (made by the authors on the basis of the information [11]).

\section{CONCLUSION}

In the result of the research a number of the efficient measures used by foreign countries in case of the counteraction to the informal economy were found. The measures mentioned above under the condition of their adaptation to the social and economic situation in the Russian regional systems can encourage the process of the improvement of the current policy of the counteraction to the informal economy in the Russian regions from the part of state authorities at the macro and meso levels of the economic system.

In our opinion the one sided solution of the problem of the reduction of the informal economy is not enough both in Russia and abroad. In this respect the integrated use of the measures mentioned above is expected to be efficient. It presents the economic encouragement and the administrative simplification of the economic activity of the economic actors what gives the opportunity of both of the direct and of the indirect government influence on the reasons of the appearance and of the growth of the share of the informal economy in the country.

\section{References}

[1] Komrakov, A.V. Rossii uroven' tenevoi ekonomiki sokhranitsya i k 2025 godu [In Russia the share of the informal economy will conserve even by 2025]. Nezavisimaya gazeta [Independent newspaper]. Available at: http://www.ng.ru/economics/2017-07-03/100_shadowec.html. Reference date 31.01.2018.

[2] Emerging from the shadows. The shadow economy to 2025. The Association of Chartered Certified Accountants. 2017. Available at: http://www.accaglobal.com/content/dam/ACCA_Global/Technical/Futur e/pi-shadow-economy.pdf. Reference date 15.01.2018.

[3] Korchagin, Yu. A. Reiting regionov po neformal'noi ekonomike za 2016 god [Rating of the regions upon the share of the informal economy in
2016]. Available at: http://www.lerc.ru/?part=articles\&art=2\&page=130. Reference date 15.01.2018.

[4] Ofitsial'nyi sait proekta «Vedenie biznesa» [Official site of the project "Doing business"]. Available at: http://russian.doingbusiness.org/custom-query. Reference date 15.01.2018.

[5] Kolomiets, A.L. Ob osnovnykh polozheniyakh opredeleniya nalogovoi nagruzki regionov Rossiiskoi Federatsii [About the basic provisions of the determination of the tax rate of the regions of the Russian Federation]. Nalogovyi vestnik [Tax bulletin]. Available at: http://nalvest.com. Reference date 15.01.2018.

[6] Uroven' bezraboticy v Shvecii snizilsja po sravneniju s 2012 godom [The unemployment rate in Sweden reduced in comparison with year 2012]. Availble at: http://www.evrokatalog.eu/articles/уровеньбезработицы-в-швеции-снизился-по-сравнению-с-2012годом/39438. Reference date 17.01.2018

[7] Reiting glav regionov po urovnyu sodeistviya konkurentsii v 2016 godu. [Ranking of the heads of the regions according to the level fo the competitive ability encouragement]. Available at: http://econ.tmbadm.ru. Reference date 15.01.2018.

[8] Official site of the company «Ernst \&Young». Available at: http://www.ey.com/. Reference date 15.01.2018.

[9] Usloviya dlya vedeniya biznesa v Rossii i v mire. Vsemirnyi bank opublikoval ezhegodnyi reiting stran po blagopriyatnosti uslovii dlya vedeniya biznesa. Ofitsial'nyi sait RIA Novosti [Conditions for business in Russia and in the world. The World Bank determined the yearly rating of the countries according to the conditions of the business activity. Official site of the RIA Novosti]. Available at: http://www.rian.ru. Reference date 15.01.2018.

[10] The Shadow Economy in Europe, 2013. About Visa Europe and Friedrich Schneider. Available at: http://www.atkearney.com/ru/financial-institutions/featured-article//asset_publisher/j8IucAqMqEhB/content/the-shadow-economy-ineurope-2013/10192. Reference date 15.01.2018.

[11] Kopylova, Yu G. Al'ternativnye podkhody k otsenke tenevoi ekonomiki Rossii i zarubezhnykh gosudarstv [Alternative approaches to the assessment of the informal economy of Russia and foreign countries]. Vestnik Volgogradskogo gosudarstvenogo universiteta. Seriya 3. Ekonomika. Ekologiya [Bulletin of the Volgograd State University. Series 3. Economics. Ecology], 2014, №3, pp. 86-93 